\title{
Stress of nursing students in clinical simulation: a randomized clinical trial
}

\author{
Estresse do estudante de enfermagem na simulação clínica: ensaio clínico randomizado \\ Tensión del estudiante de enfermería en la simulación clínica: ensayo clínico aleatorizado
}

\section{Radamés Boostel', Jorge Vinícius Cestari Felix', Carina Bortolato-Major', Edivane Pedrolo', Stela Adami Vayego', Maria de Fátima Mantovani' \\ 'Universidade Federal do Paraná. Curitiba, Paraná, Brazil.}

\author{
How to cite this article:
}

Boostel R, Felix JVC, Bortolato-Major C, Pedrolo E, Vayego SA, Mantovani MF. Stress of nursing students in clinical simulation: a randomized clinical trial. Rev Bras Enferm [Internet]. 2018;71(3):967-74.

DOI: http://dx.doi.org/10.1590/0034-7167-2017-0187

\section{Submission: 04-03-2017 Approval: 05-21-2017}

\begin{abstract}
Objective: To evaluate and compare the perception of stressors by nursing students before and after a high-fidelity clinical simulation or conventional laboratory practice class. Method: This is a randomized clinical trial conducted with 52 nursing students. Both groups had theoretical classes about cardiothoracic physical examination, followed by practice class in skill laboratory. In addition, the experimental group took part in a high-fidelity simulation scenario. Stressors were evaluated before and after class, with the application of KEZKAK questionnaire. Results: The experimental group was significantly more worried about six factors related to lack of competence and to interpersonal relationships ( $<<0.05)$, while the control group was significantly more worried about being in contact with suffering $(p=0.0315)$. Conclusion: The simulation affects students' perception of stressors and promotes their self-evaluation and critical thinking regarding the responsibility that comes with their learning.
\end{abstract}

Descriptors: Simulation; Nursing Students; Psychological Stress; Evidence-based Nursing; Randomized Controlled Clinical Trial.

\section{RESUMO}

Objetivo: Avaliar e comparar a percepção dos fatores estressores do discente de enfermagem antes e depois da simulação clínica de alta fidelidade ou da aula prática convencional de laboratório. Método: Ensaio clínico randomizado realizado com 52 discentes de enfermagem. Ambos os grupos tiveram aula teórica sobre exame físico cardiotorácico, seguida de aula prática em laboratório de habilidades. O grupo experimental participou ainda de um cenário de simulação de alta fidelidade. Os fatores estressores foram avaliados antes e após a aula, com a aplicação do questionário KEZKAK. Resultados: O grupo experimental apresentou-se significativamente mais preocupado com seis fatores relacionados à falta de competência e relação interpessoal $(p<0,05)$, enquanto no grupo controle apenas o fator contato com o sofrimento foi significativamente mais relevante $(p=$ 0,0315). Conclusão: A simulação interfere na percepção dos fatores estressores e promove uma autoavaliação e reflexão crítica pelo aluno frente à responsabilidade com o aprendizado.

Descritores: Simulação; Estudantes de Enfermagem; Estresse Psicológico; Enfermagem Baseada em Evidências; Ensaio Clínico Controlado Aleatório.

\section{RESUMEN}

Objetivo: Evaluar y comparar la percepción de los factores de tensión del estudiante de enfermería antes y después de la simulación clínica de la alta fidelidad o de la clase práctica convencional de laboratorio. Método: Ensayo clínico aleatorizado realizado con 52 estudiantes de enfermería. Ambos grupos tuvieron clase teórica sobre el análisis físico cardiotorácico, después de la clase práctica en laboratorio de habilidades. El grupo experimental participó todavía de un escenario de simulación de alta fidelidad. Los factores de tensión fueron evaluados antes y después de la clase, con la aplicación del cuestionario KEZKAK. Resultados: El grupo experimental se presentó significativamente más preocupado con seis factores relacionados a la falta de competencia y relación interpersonal ( $p$ $<0,05)$, mientras que en el grupo control solamente el factor contacto con el sufrimiento fue significativamente más relevante ( $p=$ 
0,0315). Conclusión: La simulación interfiere en la percepción de los factores de tensión y promociona una autoevaluación y el reflejo crítico por el alumno delante de la responsabilidad con el aprendizaje.

Descriptores: Simulación; Estudiantes de Enfermería; Tensión Psicológica; Enfermería Basada en Evidencias; Ensayo Clínico Controlado Aleatorio.

CORRESPONDING AUTHOR Radamés Boostel E-mail: radames.boostel@ifpr.edu.br

\section{INTRODUCTION}

Nursing education in Brazil is currently based on the National Curriculum Guidelines of the Undergraduate Program in Nursing, which guide the education of a nurse with generalist, humanist, critical, and reflective profile, based on scientific and intellectual rigor. It is based on ethics, linked with the abilities to act on health care, make decisions, communicate, lead, manage, and teach. Thus, its teaching must be centered in the student as active and participatory learning agent ${ }^{(1)}$.

To meet these guidelines, several teaching methods have been implemented, with active methodologies standing out because they are pedagogical approaches that stimulate critical-reflective teaching-learning processes, in which the student starts to be an active and participatory learning agent and the professor acts as advisor, facilitator and mediator ${ }^{(2)}$.

Clinical simulation outstands among active methodologies, employing technological tools for teaching, such as low-, medium-, and high-fidelity simulators ${ }^{(3-4)}$. Nursing professors have used this strategy for student training as a way to provide knowledge and skills that are sometimes limited during clinical practice ${ }^{(5-6)}$. This occurs because not every student have the same opportunities to perform certain procedures with the patient, which can lead to a flawed clinical experience ${ }^{(7-8)}$.

The World Health Organization points out that simulated teaching can be a strategy to overcome training shortcomings, since it expands the clinical experiences of undergraduate students, being experienced in the laboratory of simulated practices. Therefore, it provides the development of skills in a safe care context, which, therefore, brings benefits for the training, the patient, and the institution ${ }^{(9)}$.

In the simulation laboratory, the diversity of scenarios can be simulated according to the learning objectives of a given moment. Thus, students develop the required knowledge, skills, and attitudes before clinical situations. From the point of view of patient safety, the simulation allows comprehensive training for students, minimizing the chance of errors during clinical practice ${ }^{(10)}$.

In addition, the simulation strategy may contribute to the emotional preparation of future nurses, because, by enabling students to practice their skills in safe environments, feelings, such as anxiety and stress, can be worked out and a better learning can be achieved ${ }^{(11)}$.

Studies show that when nursing students practice health care, both in practice laboratory and in their first experiences with patients, they may present tremors, pallor, sweating, cold and clammy skin, emotional outburst, fainting and crying because of feelings of fear, insecurity, anxiety, and distress ${ }^{(12-13)}$.

Thus, the use of simulations can also be a stress reduction strategy for students. The first scholar to use the term stress in the health field was Hans Selye, who thus described it: nonspecific symptom from any demand on the body, be it mental or somatic effect; stressor is what leads to a stress reaction, and can be physical, mental, or emotional ${ }^{(14)}$.

Stress can lead to cognitive effects, such as decreased attention and concentration, deterioration of memory, increased rate of errors, difficulty and delay in response to stimuli. These factors are reflected in the teaching-learning process of students ${ }^{(15)}$.

A research conducted with 11 Brazilian nursing students evaluated the relationship between the stress of nursing students and patient safety ${ }^{(16)}$. The authors reported that, during the preparation of medication, the students' nervousness led to flaws, which were corrected by the professor before being administered to the patient.

Before this scenario, seeking strategies that can reduce the stress of nursing students is a challenge to nursing professors, and may contribute to the safety of patients that will be met by these students during their training process.

\section{OBJECTIVE}

To evaluate and compare the perception of stressors of nursing students before and after high-fidelity clinical simulation or conventional laboratory class.

\section{METHOD}

\section{Ethical aspects}

This research was approved by the Human Research Ethics Committee and is in accordance with Resolution no. 466/2012 for research involving human beings ${ }^{(17)}$. The participants agreed to participate in the research by signing the informed consent form. The clinical trial was registered in the Brazilian Clinical Trials Registry under the code RBR-352v3G. The use of the adapted model of KEZKAK was authorized by its authors ${ }^{(18)}$.

\section{Study design, location, and period}

The randomized clinical trial was developed in the skill and high-fidelity clinical simulation laboratory of a public university in the South region of Brazil, from August 2015 to December 2016.

\section{Population or sample; inclusion and exclusion criteria}

The population of this research consisted of students from the undergraduate program in nursing, comprising men and women over 18 years old who agreed to voluntarily participate in it. The following inclusion criteria were adopted: being student of the undergraduate program in nursing from a federal university of the South region of Brazil; being enrolled in the discipline Fundamentos para o Cuidar (Principles for the health care), in the second semester of 2015 or in the first or second semesters 
of 2016. The following exclusion criteria were adopted: being graduated in another program in the health field with competence for physical examination; having nursing technician/assistant training; having already attended the discipline Fundamentos para o Cuidar; having previous contact with patients.

\section{Study protocol}

In each semester, a random list of all included participants was generated by the researcher. After this, the Microsoft Ex$\mathrm{cel}^{\varpi}$ randbetween function was used to perform the randomization. Participants were included one by one and the program allocated them in the control or experimental groups.

The Control Group (CG) participated in the expository class on cardiothoracic physical examination, followed by conventional practice class in skill laboratory. The Experimental Group (EG) participated in the expository class on cardiothoracic physical examination, the conventional practice class in skill laboratory, and then in the high-fidelity clinical simulation.

The conventional practice class in skill laboratory followed this routine: students, divided in pairs, performed the medical history and the thoracic and cardiac physical examination with their own colleagues. Some aspects were evaluated: pulse regarding quality, rate, amplitude, and rhythm; arm circumference measures; blood pressure at rest and after physical activities, such as climbing flights of stairs and running; inspection and palpation of the precordium for identification of the ictus cordis and changes; recognition of cardiac auscultation areas to examine the rate, rhythm, heart sounds S1, S2, S3, and S4, and possible changes.

The scenario for the high-fidelity clinical simulation was drawn from Jeffries' theoretical model of simulation ${ }^{(19)}$ and run in METIman ${ }^{\circledR}$, a high-fidelity simulator. During the simulation, a high-fidelity scenario with features of infirmary was prepared. Participants were separated into pairs and met a patient according to the previously established clinical case. The simulation involved 5 minutes for the briefing, 15 minutes for the scenario, and 5 minutes for the debriefing.
During the briefing, students were told about the confidentiality of the simulation and the ethical issues involved, and were shown the environment, the functions of the simulator, and the places for verification of cardiac auscultation, pulse, and blood pressure. This moment lasted five minutes and was important to avoid anxiety caused by ignorance of the technology used.

In addition, students received the medical record with the patient's name and main complaint as well as orientation to perform the medical history and physical examination focusing on the cardiovascular system. To do so, they had to interact with patients, measure their blood pressure and heart rate, perform cardiac auscultation in all areas, and guide them regarding their health status and disease prevention.

At the beginning of the simulated scenario, vital signs and heart rate were within the normal range. After being evaluated by the students, the patient reported feeling unwell and requested further evaluation. At this point, vital signs and heart rate were changed, heart rate was increased, blood pressure was decreased, and heart rhythm was modified to atrial fibrillation.

Immediately after the simulation, a debriefing lasting 5 minutes for each pair was carried out. Then, all students that took part in the simulation discussed and reflected about their experience for 30 minutes. The pairs who passed through the experience were oriented not to share information with colleagues who had not yet experienced the simulation. Participants were told that the simulation was not part of the evaluation for the discipline.

To avoid possible communication interference between groups, the laboratory classes of EG and CG were held on consecutive days. The EG attended the class on the first day. After the end of data collection, the CG was offered a simulation class in a counter shift, on dates chosen by students, in the same way as the EG.

For the evaluation of the perception of stressors, students answered the adapted KEZKAK questionnaire (Chart 1). This questionnaire measures stressors for nursing students in clinical practice. The answers are Likert-type scale, scored from 0 to 3, depending on the degree of concern the questions cause on the students: none (0), a little (1), much (2), and very much (3).

Chart 1 - Adapted KEZKAK questionnaire about stressors ${ }^{(18)}$

\begin{tabular}{|l|l|}
\hline $01-$ Not feeling integrated into the team work & $14-$ Confusing the medication \\
\hline $02-$ Doing my work badly and harming the patient & $15-$ Fear of making mistakes \\
\hline 03 - Feeling like I cannot help the patient & 16 - Seeing a patient die \\
\hline $04-$ Causing psychological damage to the patient & $17-$ The relationship with the professor \\
\hline $05-$ Not knowing how to answer the patient's expectations & $18-$ Coming across a situation without knowing what to do \\
\hline 06 - Causing bodily harm to the patient & $19-$ Getting emotionally involved with the patient \\
\hline $07-$ Not knowing how to answer the patient & $20-$ The importance of my responsibility in caring for the patient \\
\hline $08-$ That the patient's emotions will affect me & $21-$ That the patient will not respect me \\
\hline $09-$ Talking to the patient about his/her suffering & $22-$ The relationship with the clinical practice nurse advisor \\
\hline $10-$ The relationship with healthcare professionals & $23-$ The relationship with colleagues (nursing students) \\
\hline $11-$ Being infected by the patient & $24-$ Being in an urgent situation \\
\hline $12-$ That the patient who was getting better starts getting worse & $25-$ Meeting a patient who has difficulty in communicating \\
\hline $13-$ Being infected with a contaminated needle & $26-$ Performing procedures that cause pain to the patient \\
\hline
\end{tabular}


Chart 1 (concluded)

\begin{tabular}{|l|l|}
\hline $27-$ Not knowing how to finish the dialogue with the patient & $30-$ Not finding the doctor when the situation requires his/her presence \\
\hline $28-$ Work overload & 31 - Meeting a terminal patient \\
\hline $29-$ Receiving conflicting orders & \\
\hline
\end{tabular}

The adapted KEZKAK contains 31 items divided into eight stressors: 01 Lack of competence $(1,2,3,4,5,6,11$, 13, 14, 15); 02 - Contact with suffering $(9,12,16,24,26,31) ; 03$ - Relationship with tutors and colleagues $(1,10,17,18$, 22, 23); 04 - Impotence and uncertainty $(2,3,6,12,15,18,26,30) ; 05$ - Not controlling the relationship with the patient $(5,7,15,18,24,25,27,31) ; 06$ - Emotional involvement (8, 19, 20); 07 - Feeling of being hurt in the relationship with the patient $(12,13,21)$; and 08 Overload $(25,28,29)$.

The CG answered the questionnaire immediately before and after the conventional practice class in skill laboratory. The EG answered the questionnaire immediately before the conventional practice class in skill laboratory and immediately after the debriefing of the simulation. The following sociodemographic variables were also evaluated: sex; age; and having another undergraduate degree or not.

\section{Statistical analysis of results}

Data were entered and tabulated in Microsoft Excel $^{\circledast} 2007$ spreadsheets and then analyzed with Bioestat ${ }^{\circledR}$. Descriptive statistics was used for data analysis, by calculating measures of central tendency and absolute frequencies and percentages. Stress scores obtained by KEZKAK were tabulated and submitted to statistical analyses, with estimation of absolute frequencies and percentages. Mann-Whitney and Wilcoxon tests were used for comparisons between and within groups, respectively. A 5\% significance level was used in all tests $(p<0.05)$.

\section{RESULTS}

The research included 54 participants: 13 in the second semester of 2015, 20 in the first semester of 2016, and 21 in the second semester of 2016. Participants were randomly allocated: 27 in the experimental group and 27 in the control group (Figure 1). During follow-up, two participants were excluded from the control group, one because of inadequate filling of the data collection instruments and another for abandonment of the program before the completion of the second phase of the research.

The groups were homogeneous regarding sociodemographic variables. The average ages of the EG and CG were $20.32 \pm$
1.79 and $21.11 \pm 2.47$ years old, respectively $(p=0.1956)$. Women were predominant for both groups $(85.19 \%$ - EG; $92.00 \%-C G)$. In both groups, most participants did not have another undergraduate degree $(92.59 \%$ - EG; $100.00 \%-$ CG).

Table 1 presents the stressors answered by the groups according to KEZKAK, in the moments before and after the laboratory or simulation. We chose to present only the items with significant difference in the comparison between the different moments. The CG presented significant decrease in the perception of four items as stressors, while the EG presented significant increase in the perception of nine out of 31 items as stressors and significant decrease in one item.

Table 2 presents the comparison of stressors between the groups before and after the laboratory or simulation. Before the laboratory, the two groups differed significantly in two items, since the CG showed greater concern. After the laboratory, the two groups differed significantly in seven items. For the $E G$, six items $(3,4,7,18,23$, and 25) were considered significantly more stressful. The CG pointed only item 16 ("Seeing a patient die $^{\prime \prime}$ ) as significantly more stressful. 
Table 1 - Stressors before and after laboratory or simulation, Curitiba, Paraná, Brazil, 2017

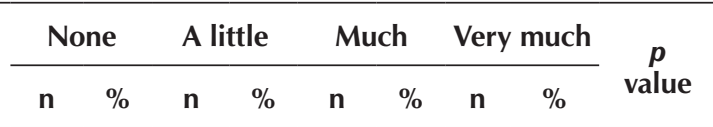

\section{Control Group}

01. Not feeling integrated into the team work

02. Doing my work badly and harming the patient

03. Feeling like I cannot help the patient

18. Coming across a situation without knowing what to do

Experimental Group

01. Not feeling integrated into the team work

03. Feeling like I cannot help the patient

04. Causing psychological damage to the patient

05. Not knowing how to answer the patient's expectations

12. That the patient who was getting better starts getting worse

15. Fear of making mistakes

20. The importance of my responsibility in caring for the patient

24. Being in an urgent situation

25. Meeting a patient who has difficulty communicating

27. Not knowing how to finish the dialogue with the patient

$\begin{array}{lccccccccc}\text { before } & 3 & 12.0 & 10 & 40.0 & 12 & 48.0 & 0 & 0.0 & 0.0109 * \\ \text { after } & 7 & 28.0 & 11 & 44.0 & 7 & 28.0 & 0 & 0.0 & \\ \text { before } & 1 & 4.0 & 1 & 4.0 & 9 & 36.0 & 14 & 56.0 & \\ \text { after } & 1 & 4.0 & 8 & 32.0 & 8 & 32.0 & 8 & 32.0 & 0.0085^{*} \\ \text { before } & 4 & 16.0 & 4 & 16.0 & 8 & 32.0 & 9 & 36.0 & \\ \text { after } & 3 & 12.0 & 9 & 36.0 & 9 & 36.0 & 4 & 16.0 & 0.0481^{*} \\ \text { before } & 0 & 0.0 & 3 & 12.0 & 9 & 36.0 & 13 & 52.0 & \\ \text { after } & 0 & 0.0 & 3 & 12.0 & 16 & 64.0 & 6 & 24.0 & 0.0191^{*}\end{array}$

$\begin{array}{llllllllll}\text { before } & 0 & 0.0 & 14 & 51.9 & 11 & 40.7 & 2 & 7.4 & 0.0192 *\end{array}$ $\begin{array}{lllllllll}\text { after } & 6 & 22.2 & 13 & 48.1 & 5 & 18.5 & 3 & 11.1\end{array}$

$\begin{array}{lllllllll}\text { before } & 1 & 3.7 & 6 & 22.2 & 11 & 40.7 & 9 & 33.3\end{array}$ $\begin{array}{llllllllll}\text { after } & 0 & 0.0 & 3 & 11.1 & 12 & 44.4 & 12 & 44.4 & 0.0481 *\end{array}$ $\begin{array}{lccccccccc}\text { before } & 3 & 11.1 & 10 & 37.0 & 7 & 25.9 & 7 & 25.9 & 0.0171^{*} \\ \text { after } & 1 & 3.7 & 6 & 22.2 & 12 & 44.4 & 8 & 29.6 & 0.01\end{array}$ $\begin{array}{llllllllll}\text { before } & 1 & 3.7 & 12 & 44.4 & 9 & 33.3 & 5 & 18.5 & 0.0481 *\end{array}$ $\begin{array}{lllllllll}\text { after } & 0 & 0.0 & 8 & 29.6 & 12 & 44.4 & 7 & 25.9\end{array}$

$\begin{array}{llllllllll}\text { before } & 2 & 7.4 & 15 & 55.6 & 8 & 29.6 & 2 & 7.4 & 0.0109 *\end{array}$ $\begin{array}{lllllllll}\text { after } & 1 & 3.7 & 11 & 40.7 & 10 & 37.0 & 5 & 18.5\end{array}$

$\begin{array}{lllllllll}\text { before } & 1 & 3.7 & 7 & 25.9 & 7 & 25.9 & 12 & 44.4\end{array}$ $\begin{array}{llllllllll}\text { after } & 0 & 0.0 & 5 & 18.5 & 6 & 22.2 & 16 & 59.3 & 0.0415^{*}\end{array}$ $\begin{array}{llllllllll}\text { before } & 0 & 0.0 & 9 & 33.3 & 14 & 51.9 & 3 & 11.1 & 0.0434^{*} \\ \text { after } & 1 & 3.7 & 4 & 14.8 & 14 & 51.9 & 8 & 29.6 & 0.04\end{array}$ $\begin{array}{lllllllllll}\text { before } & 3 & 11.1 & 8 & 29.6 & 9 & 33.3 & 7 & 25.9 & 0.0140 *\end{array}$ $\begin{array}{lllllllllll}\text { after } & 2 & 7.4 & 4 & 14.8 & 10 & 37.0 & 11 & 40.7 & 0.0140\end{array}$ $\begin{array}{lccccccccc}\text { before } & 5 & 18.5 & 13 & 48.1 & 6 & 22.2 & 3 & 11.1 & 0.0278^{*} \\ \text { after } & 1 & 3.7 & 10 & 37.0 & 12 & 44.4 & 4 & 14.8 & \end{array}$ $\begin{array}{lccccccccc}\text { before } & 4 & 14.8 & 17 & 63.0 & 5 & 18.5 & 1 & 3.7 & 0.0263^{*} \\ \text { after } & 1 & 3.7 & 14 & 51.9 & 9 & 33.3 & 3 & 11.1 & 0.026\end{array}$ Note: *Wilcoxon.

Table 2 - Comparison of stressors between the groups, Curitiba, Paraná, Brazil, 2017

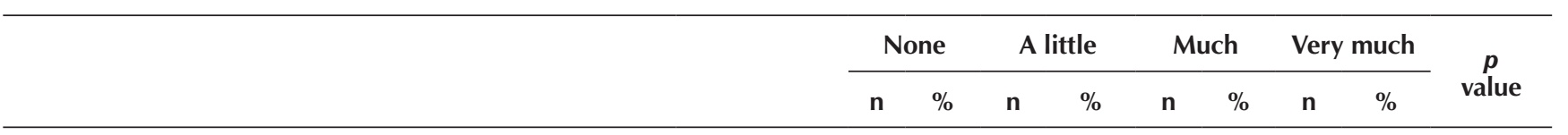

Before the laboratory

16 - Seeing a patient die

31 - Meeting a terminal patient

After the laboratory

03 - Feeling like I cannot help the patient

\begin{tabular}{lccccccccc} 
Control & 4 & 16.0 & 7 & 28.0 & 9 & 36.0 & 5 & 20.0 & $0.0363^{*}$ \\
Experimental & 6 & 22.2 & 14 & 51.9 & 5 & 18.5 & 2 & 7.4 & \\
Control & 4 & 16.0 & 10 & 40.0 & 8 & 32.0 & 3 & 12.0 & $0.0290^{*}$ \\
Experimental & 8 & 29.6 & 15 & 55.6 & 2 & 7.4 & 2 & 7.4 & \\
& & & & & & & & & \\
& & & & & & & & & \\
Control & 3 & 12.0 & 9 & 36.0 & 9 & 36.0 & 4 & 16.0 & $0.0018^{*}$ \\
Experimental & 0 & 0.0 & 3 & 11.1 & 12 & 44.4 & 12 & 44.4 & \\
\hline
\end{tabular}

To be continued 


\begin{tabular}{|c|c|c|c|c|c|c|c|c|c|c|}
\hline & & \multicolumn{2}{|c|}{ None } & \multicolumn{2}{|c|}{ A little } & \multicolumn{2}{|c|}{ Much } & \multicolumn{2}{|c|}{ Very much } & \multirow{2}{*}{$\begin{array}{c}p \\
\text { value }\end{array}$} \\
\hline & & $\mathbf{n}$ & $\%$ & $\mathbf{n}$ & $\%$ & n & $\%$ & $\mathbf{n}$ & $\%$ & \\
\hline 04 - Causing psychological damage to the patient & $\begin{array}{l}\text { Control } \\
\text { Experimental }\end{array}$ & $\begin{array}{l}7 \\
1\end{array}$ & $\begin{array}{c}28.0 \\
3.7\end{array}$ & $\begin{array}{l}9 \\
6\end{array}$ & $\begin{array}{l}36.0 \\
22.2\end{array}$ & $\begin{array}{c}5 \\
12\end{array}$ & $\begin{array}{l}20.0 \\
44.4\end{array}$ & $\begin{array}{l}4 \\
8\end{array}$ & $\begin{array}{l}16.0 \\
29.6\end{array}$ & $0.0049 *$ \\
\hline 07 - Not knowing how to answer the patient & $\begin{array}{l}\text { Control } \\
\text { Experimental }\end{array}$ & $\begin{array}{l}2 \\
0\end{array}$ & $\begin{array}{l}8.0 \\
0.0\end{array}$ & $\begin{array}{l}9 \\
8\end{array}$ & $\begin{array}{l}36.0 \\
29.6\end{array}$ & $\begin{array}{l}11 \\
10\end{array}$ & $\begin{array}{l}44.0 \\
37.0\end{array}$ & $\begin{array}{l}3 \\
9\end{array}$ & $\begin{array}{l}12.0 \\
33.3\end{array}$ & $0.0478^{*}$ \\
\hline 16 - Seeing a patient die & $\begin{array}{l}\text { Control } \\
\text { Experimental }\end{array}$ & $\begin{array}{l}5 \\
6\end{array}$ & $\begin{array}{l}20.0 \\
22.2\end{array}$ & $\begin{array}{c}5 \\
14\end{array}$ & $\begin{array}{l}20.0 \\
51.9\end{array}$ & $\begin{array}{c}11 \\
6\end{array}$ & $\begin{array}{l}44.0 \\
22.2\end{array}$ & $\begin{array}{l}4 \\
1\end{array}$ & $\begin{array}{c}16.0 \\
3.7\end{array}$ & $0.0315^{*}$ \\
\hline 18 - Coming across a situation without knowing what to do & $\begin{array}{l}\text { Control } \\
\text { Experimental }\end{array}$ & $\begin{array}{l}0 \\
1\end{array}$ & $\begin{array}{l}0.0 \\
3.7\end{array}$ & $\begin{array}{l}3 \\
1\end{array}$ & $\begin{array}{c}12.0 \\
3.7\end{array}$ & $\begin{array}{l}16 \\
11\end{array}$ & $\begin{array}{l}64.0 \\
40.7\end{array}$ & $\begin{array}{c}6 \\
14\end{array}$ & $\begin{array}{l}24.0 \\
51.9\end{array}$ & $0.0443 *$ \\
\hline 23 - The relationship with colleagues (nursing students) & $\begin{array}{l}\text { Control } \\
\text { Experimental }\end{array}$ & $\begin{array}{c}11 \\
3\end{array}$ & $\begin{array}{l}44.0 \\
11.1\end{array}$ & $\begin{array}{l}10 \\
15\end{array}$ & $\begin{array}{l}40.0 \\
55.6\end{array}$ & $\begin{array}{l}4 \\
8\end{array}$ & $\begin{array}{l}16.0 \\
29.6\end{array}$ & $\begin{array}{l}0 \\
1\end{array}$ & $\begin{array}{l}0.0 \\
3.7\end{array}$ & $0.0095^{*}$ \\
\hline 25 - Meeting a patient who has difficulty communicating & $\begin{array}{l}\text { Control } \\
\text { Experimental }\end{array}$ & $\begin{array}{l}4 \\
1\end{array}$ & $\begin{array}{c}16.0 \\
3.7\end{array}$ & $\begin{array}{l}11 \\
10\end{array}$ & $\begin{array}{l}44.0 \\
37.0\end{array}$ & $\begin{array}{l}10 \\
12\end{array}$ & $\begin{array}{l}40.0 \\
44.4\end{array}$ & $\begin{array}{l}0 \\
4\end{array}$ & $\begin{array}{c}0.0 \\
14.8\end{array}$ & $0.0342 *$ \\
\hline
\end{tabular}

Nota: *Mann Whitney.

\section{DISCUSSION}

This research had a predominance of young adults - with average age of $20.32 \pm 1.79$ (EG) and $21.11 \pm 2.47$ (CG) and women $-85.19 \%$ (EG) and 92\% (CG). The latter feature appears in undergraduate programs in nursing throughout the world, as shown by national and international studies. In a study carried out in Turkey ${ }^{(20)}, 88.5 \%(n=52)$ individuals were women, with average age of 23 years old. In the United States of America ${ }^{(21)}, 89 \%(n=134)$ of the nursing students were women, with average of 23 years old. In China ${ }^{(22)}, 92.5 \%$ $(\mathrm{n}=80)$ were women aged between 18 and 20 years old. In Brazil $^{(23)}$, a study showed that $77 \%(n=206)$ students were women aged between 18 and 21 years old. In Sweden ${ }^{(24)}, 85 \%$ $(n=361)$ were women, with average age of 23 years old.

Most participants - 92.59\% (EG) and 100\% (CG) - do not have another undergraduate degree, as corroborated by other authors, who found $96.6 \%(n=84)$ and $98.1 \%(n=102)$ participants attending their first undergraduate program ${ }^{(25-26)}$. We highlight that this feature is related to the age range found in this research, of young adults who are mostly in their vocational training phase.

Nursing training involves associating theory and practice since the early years of the program. This feature requires students to deal with complex situations, including the need to take care of someone who is becoming ill, with insufficient resources to meet the existing stressors. The previous experiences of each student will affect the perception of stressors: as a threat, leading to negative emotions, such as fear, anxiety, and anger; or as a challenge that will allow coping and overcoming ${ }^{(27)}$.

One of the objectives of this research was to evaluate whether the teaching strategy used (high-fidelity clinical simulation) affects the perception of stressors. After the laboratory class, the CG presented a significant reduction in the perception of stressors related to lack of competence and impotence/ uncertainty to meet the needs of the patient. The CG showed no significant increase in any factor when comparing the moments before and after the laboratory.
In analyzing the EG in the moments before and after the simulation, we observed a significant increase in the perception of factors related to lack of competence, not controlling the relationship with the patient, emotional involvement, and contact with suffering as stressors for the students after the simulation. Only item 1 had significant reduction after the laboratory class.

When comparing the moment before and after laboratory in the CG and EG, we verified an increase in the number of stressors, with significant difference after the laboratory class in the EG. Before the laboratory class, the CG was more worried about items 16 and 31 . Item 16 remained worrisome for the CG after the laboratory. After the laboratory class, the EG was more worried than the CG with factors related to lack of competence and to interpersonal relationships with patients, multidisciplinary team, and colleagues.

We highlight that the CG laboratory practice was held in pairs, in a relaxed and safe environment for students, since they knew each other. The results of reduction of stressors after the laboratory may be linked to the fact that these students did not experience something new. The EG, in turn, participated in a high-fidelity simulation scenario, in a new education strategy for students. Thus, the simulation may have changed students' critical thinking and provided increased awareness of their responsibility and of the required skills to meet patients. In contrast, the conventional class produced little interference in the students' perception of stressors.

Thus, it is evident that the clinical simulation allowed students to experience a near-real situation that made them think about the importance of scientific knowledge, of skills, and of their responsibility to provide the nursing care that patients need. Authors ${ }^{(11)}$ confirm this, stating that the high-fidelity simulation strategy allows approximation to reality, as well as critical reflection of attitudes by students and professors.

In this research, the perception of factors related to lack of competence, contact with suffering, relationship with professors, colleagues, and patients prevailed as significant. Studies that sought to know stressors for nursing students in clinical practice also found lack of competence as one of the main stressors 
Stress of nursing students in clinical simulation: a randomized clinical trial Boostel R, Felix JVC, Bortolato-Major C, Pedrolo E, Vayego SA, Mantovani MF.

at the beginning of practical training ${ }^{(28-31)}$. No studies evaluating the stress of nursing students in skill laboratory were found.

The beginning of clinical practice causes important changes in the emotional state of nursing students. Lack of competence, difficulties in the relationships with professors, team, and patients, and work overload are factors that contribute to a lower learning yield ${ }^{(32)}$. Knowing the main stressors and applying strategies to decrease their intensity may improve students' satisfaction and promote a quality and safe care ${ }^{(33-34)}$. In this context, the simulation strategy has been described as able to encourage the acquisition of skills, clinical reasoning, decision-making, and critical thinking ${ }^{(19,35-36)}$.

\section{Study limitations}

Some limitations must be considered concerning the generalization of the results of this research. The students had not yet had experiences with high-fidelity clinical simulation, and only one simulation session was offered. The simulation class involved only cardiothoracic physical examination, which is one of the topics of the discipline.

\section{Contributions to the fields of nursing, public health, or public policy}

This research contributes to nursing by showing that the main stressors of students are related to lack of competence and relationship difficulties. It also shows that the simulation promotes the students' awareness of their responsibility in patient care. Thus, it serves as subsidy for nursing professors to create strategies and scenarios that allow the reduction of the observed factors.

\section{CONCLUSION}

Our findings showed that the high-fidelity simulation strategy increases the perception of stressors related to lack of competence and to interpersonal relationships with patients, multidisciplinary team, and colleagues compared with the conventional practice class in skill laboratory. This increase was related to the students' capacity for self-evaluation and critical reflection concerning their responsibility to learn and the need to acquire the required skills for patient care.

\section{REFERENCES}

1. Brasil. Conselho Nacional da Educação. Câmara de educação superior. Resolução no 3, de 7 de novembro de 2001 [Internet]. Brasília: 2001 [cited 2016 Sep 25]. Available from: http://portal.mec.gov.br/cne/arquivos/pdf/CES03.pdf

2. Mitre SM, Batista RS, Mendonça JMG, Pinto NMM, Meirelles CAB, Porto CP, et al. Metodologias ativas de ensino-aprendizagem na formação profissional em saúde: debates atuais. Ciênc Saúde Colet[Internet]. 2008[cited 2017 Mar 04];13(Suppl-2):2133-44. Available from: http://dx.doi.org/10.1590/S1413-81232008000900018

3. Salvador PTCO, Martins CCF, Alves KYA, Pereira MS, Santos VEP, Tourinho FSV. Tecnologia no ensino de enfermagem. Rev Baiana Enferm [Internet]. 2015[cited 2017 Mar 04];29(1):33-41. Available from: http://www.portalseer.ufba.br/index.php/enfermagem/ article/view/9883/9540

4. Costa RRO, Medeiros SM, Martins JCA, Menezes RMP, Araújo MS. O uso da simulação no contexto da educação e formação em saúde e enfermagem: uma reflexão acadêmica. Rev Esp Saúde [Internet]. 2015[cited 2017 Mar 04];16(1):59-65. Available from: http://www.uel.br/revistas/uel/index.php/espacoparasaude/article/view/20263

5. Oliveira SND, Prado MLD, Kempfer SS. Use of simulations in nursing education: an integrative review. Rev Min Enferm [Internet]. 2014[cited 2017 Mar 04];18(2):487-504 Available from: http://www.reme.org.br/ exportar-pdf/941/en_v18n2a17.pdf

6. Kim J, Park J, Shin S. Effectiveness of simulation-based nursing education depending on fidelity: a meta-analysis. BMC Med Educ [Internet]. 2016[cited 2017 Mar 04];23(16):152. Available from: http://bmcmededuc.biomedcentral.com/articles/10.1186/ s12909-016-0672-7

7. Souza FA, Paiano M. Desafios e dificuldades enfrentadas pelos profissionais de enfermagem em início de carreira. Rev Min Enferm [Internet]. 2011[cited 2017 Mar 04];15(2):267-73. Available from: http://www.reme.org.br/artigo/detalhes/35

8. Barreto DG, Silva KGN, Moreira SSCR, Silva TS, Magro MCS. Simulação realística como estratégia de ensino para o curso de graduação em enfermagem: revisão integrativa. Rev Baiana Enferm [Internet]. 2014[cited 2017 Mar 04];28(2):208-214. Available from: https://portalseer.ufba.br/index.php/enfermagem/article/viewFile/8476/8874

9. Patient Safety Curriculum Guide: Multi-professional Edition. Geneva: World Health Organization [Internet]. 2011 [cited 2017 Mar 04]. Available from: http://whqlibdoc.who.int/publications/2011/9789241501958_eng.pdf

10. Rede Brasileira de Enfermagem e Segurança do Paciente. Estratégias para a segurança do paciente: manual para profissionais da saúde[Internet]. 2013 [cited 2017 Mar 04]. Available from: http://www.rebraensp.com.br/pdf/manual_seguranca_paciente.pdf

11. Teixeira CRS, Pereira MCA, Kusumota L, Gaioso VP, Mello CL, Carvalho EC. Evaluation of nursing students about learning with clinical simulation. Rev Bras Enferm[Internet]. 2015[cited 2017 Mar 04];68(2):311-9. Available from: http://www.scielo.br/pdf/ reben/v68n2/en_0034-7167-reben-68-02-0311.pdf

12. Gomes CO, Germano RM. Processo ensino/aprendizagem no laboratório de enfermagem: visão de estudantes. Rev Gaúcha Enferm [Internet]. 2007[cited 2017 Mar 04];28(3):401-8. Available from: http://www.seer.ufrgs.br/index.php/RevistaGauchadeEnfermagem/ article/view/4693/2598

13. Musso ML, Vargas BA, Torres MB, Del Canto MJC, Meléndez CG, Balloqui MFK, et al. Factors derived from the intrahospitable laboratories that cause stress in infirmary students. Rev Latino-Am Enfermagem [Internet]. 2008[cited 2017 Mar 04];16(5):805-11. Available from: http://dx.doi.org/10.1590/S0104-11692008000500002

14. Selye H. The stress of life. New York; McGraw-Hill; 1956.

15. Silva VLS, Chiquito NC, Andrade RAPO, Brito MFP, Camelo SHH. Fatores de estresse no último ano do curso de graduação em 
Stress of nursing students in clinical simulation: a randomized clinical trial Boostel R, Felix JVC, Bortolato-Major C, Pedrolo E, Vayego SA, Mantovani MF.

enfermagem: percepção dos estudantes. Rev Enferm UERJ [Internet]. 2011[cited 2017 Mar 04];19(1):121-6. Available from: http:// www.facenf.uerj.br/v19n1/v19n1a20.pdf

16. Santos VEP, Radünz V. O estresse de acadêmicas de enfermagem e a segurança do paciente. Rev Enferm UERJ [Internet]. 2011[cited 2017 Mar 04];19(4):616-20. Available from: http://www.facenf.uerj.br/v19n4/v19n4a19.pdf

17. Brasil. Conselho Nacional de Saúde. Resolução no 466, de 12 de dezembro de 2012 [Internet]. Brasília, 2012 [cited 2016 Aug 12]. Available from: http://bvsms.saude.gov.br/bvs/saudelegis/cns/2013/res0466_12_12_2012.html

18. Barroso I, Vilela I, Rainho C, Correia T, Antunes C. Adaptação para a língua portuguesa do questionário KEZKAK: instrumento de medida dos factores de stresse dos estudantes de enfermagem na prática clínica. Rev Invest Enferm [Internet]. 2008 [cited 2017 Mar 04];17(2):34-40. Available from: https://bibliotecadigital.ipb.pt/bitstream/10198/1115/1/ARTIGO\%20KAZKAK.pdf

19. Jeffries PR. Simulation in nursing education: from conceptualization to evaluation. $2^{\text {a }}$ ed. New York: National League of Nursing, 2012.

20. Tuzer H, Dinc L, Elcin M. The effects of using high-fidelity simulators and standardized patients on the thorax, lung, and cardiac examination skills of undergraduate nursing students. Nurse Educ Today [Internet]. 2016[cited 2017 Mar 04];45120-5. Available from: https://www.ncbi.nlm.nih.gov/pubmed/27449150

21. Bronson S. Autonomy support environment and autonomous motivation on nursing student academic performance: an exploratory analysis. Nurse Educ Today [Internet]. 2016[cited 2017 Mar 04];44103-108. Available from: http://www.sciencedirect.com/ science/article/pii/S0260691716300715

22. Au ML, Lo MS, Cheong W, Wang SC, Van IK. Nursing students' perception of high-fidelity simulation activity instead of clinical placement: a qualitative study. Nurse Educ Today [Internet]. 2016[cited 2017 Mar 04];3916-21. Available from: https://www.ncbi. nlm.nih.gov/pubmed/27006029

23. Moura IH, Nobre RS, Cortez RMA, Campelo V, Macêdo SF, Silva ARV. Qualidade de vida de estudantes de graduação em enfermagem. Rev Gaúcha Enferm [Internet]. 2016[cited 2017 Mar 04];37(2):e55291. Available from: http://www.seer. ufrgs.br/ index.php/RevistaGauchadeEnfermagem/article/view/55291/37252

24. Rejnö A, Nordin P, Forsgren S, Sundell Y, Rudolfsson G. Nursing students' attendance at learning activities in relation to attainment and passing courses: a prospective quantitative study. Nurse Educ Today [Internet]. 2016[cited 2017 Mar 04];7(50):36-41. Available from: http://www.nurseeducationtoday.com/article/S0260-6917(16)30290-8/abstract

25. Carvalho AMB, Araújo SN, Lima IRSL, Silva ECA. Motivational factors related to the choice of graduation in Nursing. J Health Sci Inst [Internet]. 2015[cited 2016 Aug 5];33(1):56-62. Available from: https://www.unip.br/comunicacao/publicacoes/ics/ edicoes/2015/01_jan-mar/V33_n1_2015_p56a62.pdf

26. Araújo MAN, Lunardi Filho WD, Leite LRC, Mal RTK, Silva AA, Souza JC. Nursing students' quality of life. Rev Rene [Internet]. 2014[cited 2016 Nov 10];15(6):990-7. Available from: http://www.repositorio.ufc.br/bitstream/riufc/11309/1/2014_art_manaraujo.pdf

27. Lazarus RS, Folkman S. Stress, appraisal and coping. New York: Springer Publishing, 1984.

28. Benavente SBT, Silva RM, Higashi AB, Guido LA, Costa ALS. Influence of stress factors and socio-demographic characteristics on the sleep quality of nursing students. Rev Esc Enferm USP [Internet] 2014[cited 2016 Sep 14];48(3):514-20. Available from: http:// www.scielo.br/pdf/reeusp/v48n3/pt_0080-6234-reeusp-48-03-514.pdf

29. Hirsch CD, Barlem ELD, Almeida LK, Tomaschewski-Barlem JG, Figueira AB, Lunardi VL. Coping strategies of nursing students for dealing with university stress. Rev Bras Enferm [Internet] 2015[cited 2016 Nov 10];68(5):501-8. Available from: http://www.scielo. $\mathrm{br} / \mathrm{pdf} /$ reben/v68n5/en_0034-7167-reben-68-05-0783.pdf

30. Suen WQ, Lim S, Wang W, Kowitlawakul Y. Stressors and expectations of undergraduate nursing students during clinical practice in Singapore. Int J Nurs Pract [Internet] 2016[cited 2016 Dec 1];22(6):574-83. Available from: https://www.ncbi.nlm.nih.gov/ pubmed/27507126

31. López-Cruz V, Hernández-Castañón MA, Mendonza-Zamora A, Villarreal-Ríos E, Gasca-Ramírez MA. Support to nursing students in their first clinical practice in stressful situations. Rev Enferm IMSS[Internet] 2016[cited 2016 Nov 10];24(3):165-70. Available from: http://www.medigraphic.com/pdfs/enfermeriaimss/eim-2016/eim163c.pdf

32. Dias EP, Stutz BL, Resende TC, Batista NB, Sene SS. Expectations of nursing students first stage in front of the health institutions. Rev Psicopedag [Internet] 2014[cited 2017 Jan 12];31(94):44-55. Available from: http://pepsic.bvsalud.org/scielo. php?script $=$ sci_arttext\&pid $=$ S0103-84862014000100006\&lng $=$ pt\&nrm $=$ iso

33. Lima JA, Carrilho AB, Santos LD, Lima UTS. Expectations about hospital internship for nursing students. Rev Aten Saúde [Internet] 2016[cited 2016 Nov 10];14(48):5-10. Available from: http://seer.uscs.edu.br/index.php/revista_ciencias_saude/article/ view/3372/pdf

34. Bublitz S, Guido LA, Lopes LFD, Freitas EO. Association between nursing students' academic and sociodemographic characteristics and stress. Texto Contexto Enferm [Internet] 2016[cited 2017 Jan 12];25(4):e2440015. Available from: http://dx.doi. org/10.1590/0104-07072016002440015

35. Pina-Jimenez I, Amador-Aguilar R. Nursing teaching using simulators, theoretical and pedagogical considerations to design a didactic model. Enferm Univ [Internet] 2015[cited 2016 Dec 19];12(3):152-9. Available from: http://dx.doi.org/10.1016/j. reu.2015.04.007

36. Baptista RC, Paiva LA, Gonçalves RF, Oliveira LM, Pereira MF, Martins JC. Satisfaction and gains perceived by nursing students with medium and high-fidelity simulation: a randomized controlled trial. Nurse Educ Today [Internet] 2016 [cited 2016 Dec 1];46:127-32. Available from: http://dx.doi.org/10.1016/j.nedt.2016.08.027 